\title{
The Role of Service Quality, Perceived Value and Trust on Calculative Commitment and Loyalty Intention
}

\author{
A. Kungumapriya, K. Malarmathi \\ Bharathiar University, Coimbatore, India
}

\begin{abstract}
Global mobile communication is one of the most dynamic and important service markets. Several researchers suggest using a theoretical approach to develop a much deeper insight into key marketing constructs, such as service quality, customer perceived value, customer satisfaction, perceived switching costs, corporate image, and customer loyalty, is vital to the mobile communications market. This paper aims to investigate the role of service quality, trust, and perceived value on calculative commitment and loyalty intention in the customers of mobile telephone network service providers (MTNSPs). To notify the meaningful factors for the calculative commitment and loyalty intention of the users in using mobile phones, this study focuses on the effect of service quality and perceived value in the trust and identifying the role of trust in forming customer loyalty. As many as 125 users of mobile phone users-house wife were surveyed in Coimbatore, Tamil Nadu, India. The data are analyzed by path analysis. This study shows that service quality has a direct and positive effect on trust, trust has a direct and positive effect on calculative commitment, calculative commitment has a direct and positive effect on loyalty, and direct and positive relationship between perceived value and calculative commitment, perceived value, and loyalty are also confirmed. In terms of mobile telecommunication systems, it is found that the users may exhibit noticeable differences in using this service. This study provides important hints to strengthen the relationship between the network service providers and their customers.
\end{abstract}

Keywords: calculative commitment, customer loyalty, loyalty intention, perceived value, service quality and trust

\section{Introduction}

The rapid growth and dynamic nature of the global mobile communications industry have attracted the interests of several marketing academics and practitioners. Researchers have examined the relationships between several behavioral constructs in the mobile communications markets. Given the large number of existing mobile phone users, the rapid industry growth rate, the continuing technology advances that are a feature of the industry, and the number of multi-nationals that are involved in supplying mobile communication components, telecommunication companies must understand their customers' changing perceptions in order to keep their current customers engaged and cultivate new customers. Customer loyalty is important for both the

A. Kungumapriya, MBA, M.Phil., Ph.D., research scholar, Research and Development, Bharathiar University, Coimbatore, India.

K. Malarmathi, M.Sc., MBA, Ph.D., professor, Bharathiar School of Management and Entrepreneur Development, Bharathiar University, Coimbatore, India.

Correspondence concerning this article should be addressed to A. Kungumapriya, 1/26, Erisinampatti post, Udumalpet Taluk, Tiruppur District, Coimbatore 642207, India. 
firm and the customer. As regards the firm, loyal customers are willing to make repeat purchases in the business that delivers value beyond their expectation. Loyal customers often will over time bring substantial revenues and demand less attention from the firms they patronize. The determinants of customer loyalty include service quality (Zeithaml, Berry, \& Parasuraman, 1996), perceived service value (Yang \& Peterson, 2004), customer satisfaction (Chandrashekaran et al., 2007; Lai, Griffin, \& Babin, 2009), customer trust and commitment (Garbarino \& Johnson, 1999). For this study, we have taken service quality, trust, and perceived value, calculative commitment and loyalty.

\section{Mobile Telephone Communication Industry}

In telecommunications sector, the year 2015-2016 has been busy and eventful year. In the telecom sector at the end of the financial year, the subscriber base was 1,058.86 million out of which 1,033.63 million was wireless subscribers. This is witnessed substantial growth in the number of subscribers during the year 2015-2016. The urban tele-density increased from 148.61 to 154.01 . The Internet subscriber base in the country as on 31st March, 2016 stood at 342.65 million as compared to 302.35 million as on 31st March, 2015. The total broadband subscriber base of the country increased from 99.20 million as on 31st March, 2015 to 149.75 million as on 31st March, 2016. Quality of service is one of the most important policies and programmes of Telecom Regulatory Authority of India in respect of telecom sector (TRAI 2015-2016) ${ }^{1}$.

\section{Theoritical Background}

The conceptualization and operationalization of the main concepts in this study are based on relevant literature, presented below. Additionally, hypotheses regarding the relationships among the concepts are developed.

\section{Service Quality}

More recently, based on Brady and Cronin's model, Lu et al. developed a multidimensional and hierarchical model to measure mobile service quality. They proposed that mobile service quality was composed of three primary dimensions: interaction quality, environment quality, and outcome quality, and each primary dimension further included sub-dimensions. According to Zeithaml (1988), service quality could be conceptualized as the consumers' judgment about the overall excellence or superiority of a service. High service quality could attract new customers, retain existing customers, and also lure customers away from other service competitors whose service quality is perceived as poorer (Babakus et al., 2004). Service quality is especially important in the context of mobile services, since previous researches have pointed out, as the key factors of mobile companies' success, the service quality and customer satisfaction (Yang \& Peterson, 2004). Service quality is a critical factor for companies’ profitability and market success (Aydin \& Özer, 2005). According to Shin and Kim (2008), service quality is defined as the consumers' overall impression of the relative efficiency of a service provider. One consensus that has emerged from several recent studies is that researchers empirically modelling the service quality construct have consistently identified at least three primary dimensions of service quality: interaction quality, physical environment quality, and outcome quality (Brady \& Cronin, 2001; Clemes, Shu, \& Gan, 2014; Clemes et al., 2010; Clemes et al., 2007; Dagger et al., 2007; Lu et al., 2009; C. Martínez \& G. Martínez, 2008). These three primary dimensions are used in this current study.

\footnotetext{
1 TRAI (Telecom Regulatory authority of India). Annual report (2015-2016). Retrieved from www.trai.gov.in/.
} 
The service marketing literature suggests that the interpersonal interactions between mobile communications service providers and their customers significantly impact on mobile communications service quality as perceived by customers (Kim \& Yoon, 2004; Lai et al., 2007; Lim et al., 2006; Lu et al., 2009; Wang et al., 2004). Dabholkar et al. (1996) suggested that in a retail store the physical aspects are similar to the tangible dimension of SERVQUAL, but that the physical aspects have a broader meaning. Lai et al.'s (2007) and Wang et al.'s (2004) findings showed that the store environments, such as whether the physical facilities provided by mobile communications service providers are visually appealing and whether employees of mobile communications service providers are well dressed and neat in appearance, have a significant impact on customers' overall perceptions of mobile communications service quality in the mobile communications market.

Outcome quality, or technical quality, is what customers receive after the service delivery process and buyer-seller interactions are complete (Grönroos, 1984). Rust and Oliver (1994) defined customer satisfaction as "a summary cognitive and affective reaction to a service incident" that results from the comparison of customers' perceptions of service quality with their expectations of service performance.

\section{Trust}

Trust is a multidimensional concept (Mayer, Davis, \& Schoorman, 1995; Rousseau, Sitkin, Burt, \& Camerer, 1998) and trust is a specific belief about the trustee's integrity, competence, and benevolence (Doney \& Cannon, 1997; Ganesan, 1994; Gefen, 2004). Trust plays an important role in determining customer loyalty. When customers trust the service provider, they will continually use the service and even recommend the service to potential customers (Deng et al., 2010). In telecommunications market, Chiou and Droge (2006) pointed out that customer trust has been shown to be important and is related to the emotional nature of consumer loyalty long-term orientation in the relationship. For instance, researchers found that trust positively influences customers' attitude and behavior intention in mobile commerce context (Deng et al., 2010). Pirc (2006) also claimed that customer trust in the mobile service provider has a positive and direct effect on loyalty in Slovenia mobile phone industry. Similar results are also reported in Taiwan ISP (Internet service provider) research by Chiou (2004) and in the United Kingdom mobile phone research by Ranaweera and Prabhu (2013). Therefore, an ISP which has a higher level of brand trust will tend to have a higher level of attitudinal and behavioral loyalty among the consumers. The Indian mobile phone industry is a high churn pre-paid market. Churn rates have escalated with increased competition and deregulation. Increased customer churn results in rising customer acquisition costs (a new customer can cost a mobile phone company between US\$300 and US\$600 in sales support, marketing and commissions) and lower average monthly billings (Borna, 2000). Mobile phone marketing managers generally focus on the product features, price, and delivery in their marketing strategy. Since, the scope for product differentiation is limited in telecom sector, an understanding of factors which drive customer loyalty is beneficial for customer relationship managers to develop and reinforce marketing strategies to increase retention.

Trust is known as a foundation of a long-term relationship, as a possible advanced exchange relationship between buyers and sellers (Hong \& Cho, 2011). Customer trust refers to the customers' perceptions of attributes of service providers, including the ability, integrity, and benevolence of the providers (Deng et al., 2010). Additionally, customer trust relates to the perception of customers on the ability of a brand to fulfill its promise while expertise refers to a brand capability of realizing its promises (Ou et al., 2011). 


\section{Perceived Value}

According to Zeithaml (1988), perceived value could be defined as the consumers' overall assessment of the benefits of a product or service, based in perceptions of what is received and what is given. Other authors conceptualize service perceived value as a trade-off between total benefits and total sacrifices, whether these sacrifices are monetary or non-monetary (Al-Debei, Al-Lozi, \& Papazafeiropoulo, 2013). In the mobile communications sector, the service perceived value could be defined as the evaluation of the benefits of a service by customers, based on their advance sacrifices and ex-post perceived performance when they use mobile services (Kuo, Wu, \& Deng, 2009). This way, customers integrate their perceptions of what they get and what they give up to obtain mobile communication services. Although service quality is an important element of service value, previous research suggests that price and value for money are other key components, meaning what consumers pay to acquire a specific service ( $\mathrm{Lu}, \mathrm{Lu}, \&$ Jen, 2011). So, according to the consumers' monetary perspective, service value is created when less money is paid for services (Kuo et al., 2009).

According to Edward, George, and Sarkar (2010), consumers made purchase decisions based on the benefits and costs involved, and the concept of service value generally held the notion of the quality and benefits consumers get for a unit of money - the price, involving the trade-off between what consumers receive and what they give.

\section{Commitment}

Commitment is recognized as an essential ingredient for successful long-term relationships (Dwyer, Schurr, \& Oh, 1987; Morgan \& Hunt, 1994). Commitment has been defined as "an enduring desire to maintain a valued relationship” (Moorman, Zaltman, \& Deshpande, 1992, p. 316). Gundlach, Achrol, and Mentzer (1995) argued that commitment has three components: an instrumental component of some form of investment, an attitudinal component that may be described as affective commitment or psycho-logical attachment, and a temporal dimension indicating that the relationship exists over time.

Lin and Wu (2011) considered customer commitment as a consumer's persistent wish and attempted to retain a relationship with a service provider. In terms of their relationship with service quality, positive overall service quality impacts on commitment that customers have towards a particular brand and the associated service provider (Jahanzeb et al., 2011).

\section{Loyalty Intention}

Moreover, loyal customers are less likely to change provider because of price, while they also tend to recommend the business to others (Reichheld \& Sasser, 1990; Reichheld \& Teal, 1996). Such observations highlight the critical importance of customer loyalty for companies and especially for those operating in service industries.

Customer loyalty refers to a favorable attitude towards a particular brand in addition to purchasing it repeatedly (Day, 1969); a relationship between relative attitude towards an entity and repeat patronage behavior (Dick \& Basu, 1994); a situation when repeat purchase behavior is accompanied by a psychological bond; and repeat purchase intentions and behaviors. Customer loyalty sometimes has been operationalized as a behavioral measure and at other times as an attitude. The concept of customer loyalty is understood as a combination of customers' favorable attitude and the behavior or repurchases (Kim \& Yoon, 2004).

Customer loyalty is affected by customer satisfaction and the switching barrier (Dick \& Basu, 1994; Gerpott et al., 2001; Lee \& Cunningham, 2001). Customers experiencing high-level satisfaction are likely to 
remain with their existing providers and maintain their subscription. Customer loyalty sometimes has been operationalized as a behavioral measure and at other times as an attitude. Behavioral measures include probability of purchase (Farley, 1964), purchase frequency (Brody \& Cunningham, 1968), repeat purchase behavior (Brown, 1952), purchase sequence, and multiple aspects of purchase behavior. Attitudinal approaches are focused mainly on brand recommendations (Boulding et al., 1993), resistance to superior products (Narayandas, 1996), willingness to pay a price premium (Zeithaml et al., 1996), and repurchase intention (Cronin \& Taylor, 1992; Anderson \& Sullivan, 1993).

Customer loyalty is important for both the firm and the customer. As regards the firm, loyal customers are willing to make repeat purchases in the business that delivers value beyond their expectation. Loyal customers often will over time bring substantial revenues and demand less attention from the firms they patronize (Yang \& Peterson, 2004). Indeed, it is common to find loyal customers sympathizing with poor service, displaying less sensitivity to price, and disseminating positive word of mouth about the service to others (Yang \& Peterson, 2004). On the other hand, loyalty is important to customers because loyal customers incur less time and costs in searching for information and evaluating purchase decisions and also incur less or no switching costs. Consequently, customer loyalty is beneficial to both the customer and the service provider and so is a major source of sustained competitive edge (Keaveney, 1995). Based on the above discussed literature, the following hypothesis is framed.

\section{Concept Framework and Hypothesis}

\section{Service Quality}

Chadha and Kapoor (2009) focused their study to test the effect of switching cost, service quality, and customer satisfaction on customer loyalty in cellular services. The results of the study found a positive relationship between the switching cost and customer perceived service quality, customer satisfaction and customer loyalty. Greece Ilias Santouridis and Panagiotis Trivellas (2010) analyzed the impact of service quality and customer satisfaction on customer loyalty in mobile telephony in Greece. The analysis of the research data showed that service quality is a major predictor of both customer satisfaction and loyalty. Satisfaction has a very significant positive effect on loyalty by totally mediating the influence of the pricing structure and billing system service quality dimensions. Wong and Sohal (2003) examined the effect of service quality and customer loyalty on two levels of retail relationships: person-to-person (salesperson level) and person-to-firm (store level) and found a positive relationship between service quality and customer loyalty. A significant relationship was found to exist between service quality and customer loyalty in the commercial airline industry (Ostrowski et al., 1993; Zins, 2001).

People tend to make trust related assumptions about others on the basis of their knowledge (McKnight, Cummings, \& Chervany, 1998). When people feel that the performance of the ASP (Application Service Providers) is of high quality, they are likely to postulate that the ASP has beneficial characteristics, i.e., people assume that ASP is competent and beneficial when they feel that the quality of system, information, and service is satisfactory. In turn, it will promote trust in the ASP. McKnight et al. (2002a) noted that the perceived quality of web site directly affects trust for web vendors in their web trust model. The relationship between the perceived quality of others and trust has been supported in the web-based information system environment (Belanger, Hiller, \& Smith, 2002; McKnight, Choudhury, \& Kacmar, 2002b). Service quality affects trust toward ASP (Farn \& Huang, 2009). Therefore, it is hypothesized that system, information quality of ASP 
system, and service quality of ASP have direct positive effects on trust. We also believe that service quality has an impact on trust and customer loyalty. Based on the literature discussed above, the following hypotheses are proposed.

H1: Service quality has a direct and positive effect on trust.

H2: Service quality has a direct and positive effect on loyalty.

\section{Trust}

Trust leads to a high level of affective commitment. Trust is positively related to commitment in buyer-seller relationships (Ganesan \& Hess, 1997). Trust addresses central social needs of the customer, the fulfillment of which leads to an affective commitment to the relationship (Hennig-Thurau \& Klee, 1997). When customers trust the supplier, they strongly believe in the future potential of the relationship (Walter \& Ritter, 2003). De Ruyter et al. (2001) reported a positive impact of trust on affective commitment in supplier-customer relationships in high-technology markets. Wang (2002) reported the mediating effect of affective commitment on trust-loyalty link of the customer relationship. In business-to-business services context, Gounaris (2005) found a significant influence of trust on affective commitment, which in turn influences intention to invest and intention to stay in a relationship. Based on this literature, the following hypothesis is proposed.

H3: Trust has a direct and positive effect on calculative commitment.

\section{Perceived Value}

In the Thai mobile service context, value has a positive influence to customer retention (Leelakulthanit \& Hongcharu, 2011). In the Chinese mobile data services, customer value also has direct effects on repurchase intention (Qian et al., 2011; Wang et al., 2004) and attitudinal loyalty (Qian et al., 2011). Likewise, Lien et al. (2011) found a significant link between perceived value and behavioral intentions in Taiwanese online shopping context. Similar findings are also reported in the Taiwanese mobile commerce context (Chiou, 2004).

Fujun Lai, Mitch Griffin, and Barry J. Babin (2009) analyzed how quality, value, image, and satisfaction create loyalty at a Chinese telecom. Integrative model is used to examine the relations among service quality, value, image, satisfaction, and loyalty in China. Results revealed that service quality directly influences both perceived value and image perceptions, that value and image influence satisfaction, that corporate image influences value, and that both customer satisfaction and value are significant determinants of loyalty. Thus, value has both a direct and indirect (through satisfaction) impact on customer loyalty. Other variables mediate the impact of both service quality and corporate image on customer loyalty. Dong-Hee Shin (2015) in his study "Effect of the Customer Experience on Satisfaction With Smartphones: Assessing Smart Satisfaction Index With Partial Least Squares" found that the perceived value and customer satisfaction are key variables mediating the relationship between quality and customer loyalty. Based on this literature, the following hypotheses are proposed.

H4: Perceived value has a direct and positive effect on trust.

H5: Perceived value has a direct and positive effect on calculative commitment.

H6: Perceived value has a direct and positive effect on loyalty Intention.

\section{Calculative Commitment}

Moreover, numerous studies have recently demonstrated that there is a positive correlation between customer commitment and customer repurchase. Affective and calculative commitment positively affects the customers' intention to continue a relationship with their service provider in a Central and Eastern European in 
the service sector (Cater \& Zabkar, 2009). Calculative commitment and affective commitment positively influence behavioral intentions (Cater \& Zabkar, 2009; Fullerton, 2005). The more time and effort customers have invested in the relationship with their service provider, the less inclined the customers are to break up that relationship (Bügel et al., 2010). Customers with high levels of calculative commitment will be unwilling to switch to another service provider because of the great switching costs (Bügel et al., 2010; Cater \& Zabkar, 2009).

Studies on customer behavior have undergone tremendous developments in the past few decades. For instance, during the 1970s and 1980s, scholars have emphasized the role of customer satisfaction in determining consumer behavior (Oliver, 1999). However, more recently, researchers have expanded this conceptualization beyond satisfaction into the realms of customer commitment (Garbarino \& Johnson, 1999) and customer loyalty (Berry, 1995). This new interest is underscored by the long held view that mere acquisition of new customers and getting them satisfied cannot guarantee sustained business and that a loyal customer base is the only assurance firms have against possible losses (Berry, 1995). Based on the above discussed literature, the following hypothesis is framed.

H7: Calculative commitment has a direct and positive relationship on loyalty intention.

\section{Research Methodology}

\section{Measurement of Variables}

For the validation of research hypothesis, the following measures derived from the review of literature are service quality, perceived value, trust, calculative commitment, and loyalty. To measure the service quality, the questions were adapted from the research conducted by (Brady \& Cronin, 2001; Clemes et al., 2007; 2010; 2011; Dagger et al., 2009; C. Martínez \& G. Martínez, 2008). To measure the perceived value, the variables and questions were adopted from Chiao-Chen Chang (2015), and to measure the trust, the questions were adopted from X-peng et al. (2014) and Kim, Gupta, and Koh (2011). The dimensions of commitment that is calculative are operationalized using the scales developed by Bansal, Irving, and Taylor (2004) and Gustafsson et al. (2005). All the items are measured on a five-point Likert scale ranging from "very strongly disagree” to "very strongly agree".

Table 1

Measurement of Variables

\begin{tabular}{llll}
\hline S. No & Variables & Number of items & Cronbach alpha \\
\hline 1 & Service quality & 6 & 0.774 \\
2 & Perceived value & 3 & 0.634 \\
3 & Trust & 6 & 0.900 \\
4 & Calculative commitment & 7 & 0.871 \\
5 & Customer loyalty & 10 & 0.879 \\
\hline
\end{tabular}

\section{Data Collection and Sample Characteristics}

Data were obtained from the house wives using mobile phones of cellular mobile services in Coimbatore, Tamil Nadu State, with the help of questionnaires. Purposive sampling method was used to collect the data from the customers. Pre- and post-paid subscribers of GSM (global system for mobile) services were included in the present study. A total of 125 questionnaires were completed in all aspects. 
Table 2

Demographic Profile of the Respondents

\begin{tabular}{llll}
\hline I & Age group & Number of respondents & Percentage (\%) \\
\hline $18-22$ & 9 & 7.2 \\
& $23-27$ & 20 & 16.0 \\
$28-32$ & 32 & 25.6 \\
& $33-37$ & 51 & 40.8 \\
& 38 and above & 13 & 10.4 \\
\hline II & Education & & 44 \\
\hline & Up to 12th & 55 & 40 \\
& Under graduate & 50 & 16 \\
\hline III & Post graduate & 20 & 9.6 \\
\hline & Household income (in Rs) & & 52.8 \\
& Below 10,000 & 12 & 25.6 \\
& 10,001-30,000 & 66 & 12.0 \\
\hline
\end{tabular}

\section{Data Analysis and Findings}

Data collected have been analyzed using different statistical tools. SPSS (Statistical Product and Service Solutions) 11.5 was used for assessment of the reliability of dimensions and testing the hypothesis. For the purpose of analysis, path analysis is used to find the significance or relationship between variables.

(1) Reliability analysis

The reliability of items was assessed by computing the coefficient of Cronbach alpha. Cronbach alpha measures the internal consistency of the items. For the purpose of this research, alpha coefficient has been computed separately to assess the reliability of the scales adopted in the study. Results of reliability analysis are shown in Table 1 . If coefficient alpha is above 0.60 , it is considered to be reliable. All alpha coefficients range from 0.634 to 0.900 , thereby, indicating good consistency among the items within each dimension and scale.

(2) Result (default model)

Minimum was achieved.

Chi-square $=2.596$

Degrees of freedom $=2$

Probability level $=0.273$

(3) Model fit summary

Table 3

CMIN

\begin{tabular}{llllll}
\hline Model & NPAR & CMIN & DF & $P$ & CMIN/DF \\
\hline Default model & 13 & 2.596 & 2 & 0.273 & 1.298 \\
Saturated model & 15 & 0.000 & 0 & & 28.727 \\
Independence model & 5 & 287.272 & 10 & 0.000 & 27 \\
\hline
\end{tabular}


Table 4

RMR, GFI

\begin{tabular}{lllll}
\hline Model & RMR & GFI & AGFI & PGFI \\
\hline Default model & 0.009 & 0.992 & 0.938 & 0.132 \\
Saturated model & 0.000 & 1.000 & & 0.298 \\
Independence model & 0.210 & 0.447 & 0.171 & \\
\hline
\end{tabular}

Table 5

Baseline Comparisons

\begin{tabular}{|c|c|c|c|c|c|}
\hline Model & $\begin{array}{l}\text { NFI } \\
\text { Delta 1 } \\
\end{array}$ & $\begin{array}{l}\text { RFI } \\
\text { rho 1 }\end{array}$ & $\begin{array}{l}\text { IFI } \\
\text { Delta } 2\end{array}$ & $\begin{array}{l}\text { TLI } \\
\text { rho } 2\end{array}$ & CFI \\
\hline Default model & 0.991 & 0.955 & 0.998 & 0.989 & 0.998 \\
\hline Saturated model & 1.000 & & 1.000 & & 1.000 \\
\hline Independence model & 0.000 & 0.000 & 0.000 & 0.000 & 0.000 \\
\hline
\end{tabular}

Table 6

Parsimony-Adjusted Measures

\begin{tabular}{llll}
\hline Model & PRATIO & PNFI & PCFI \\
\hline Default model & 0.200 & 0.198 & 0.200 \\
Saturated model & 0.000 & 0.000 & 0.000 \\
Independence model & 1.000 & 0.000 & 0.000 \\
\hline
\end{tabular}

Table 7

\begin{tabular}{llll} 
NCP & \multicolumn{3}{l}{} \\
\hline Model & NCP & LO 90 & HI 90 \\
\hline Default model & 0.596 & 0.000 & 9.144 \\
Saturated model & 0.000 & 0.000 & 0.000 \\
Independence model & 277.272 & 225.663 & 336.305 \\
\hline
\end{tabular}

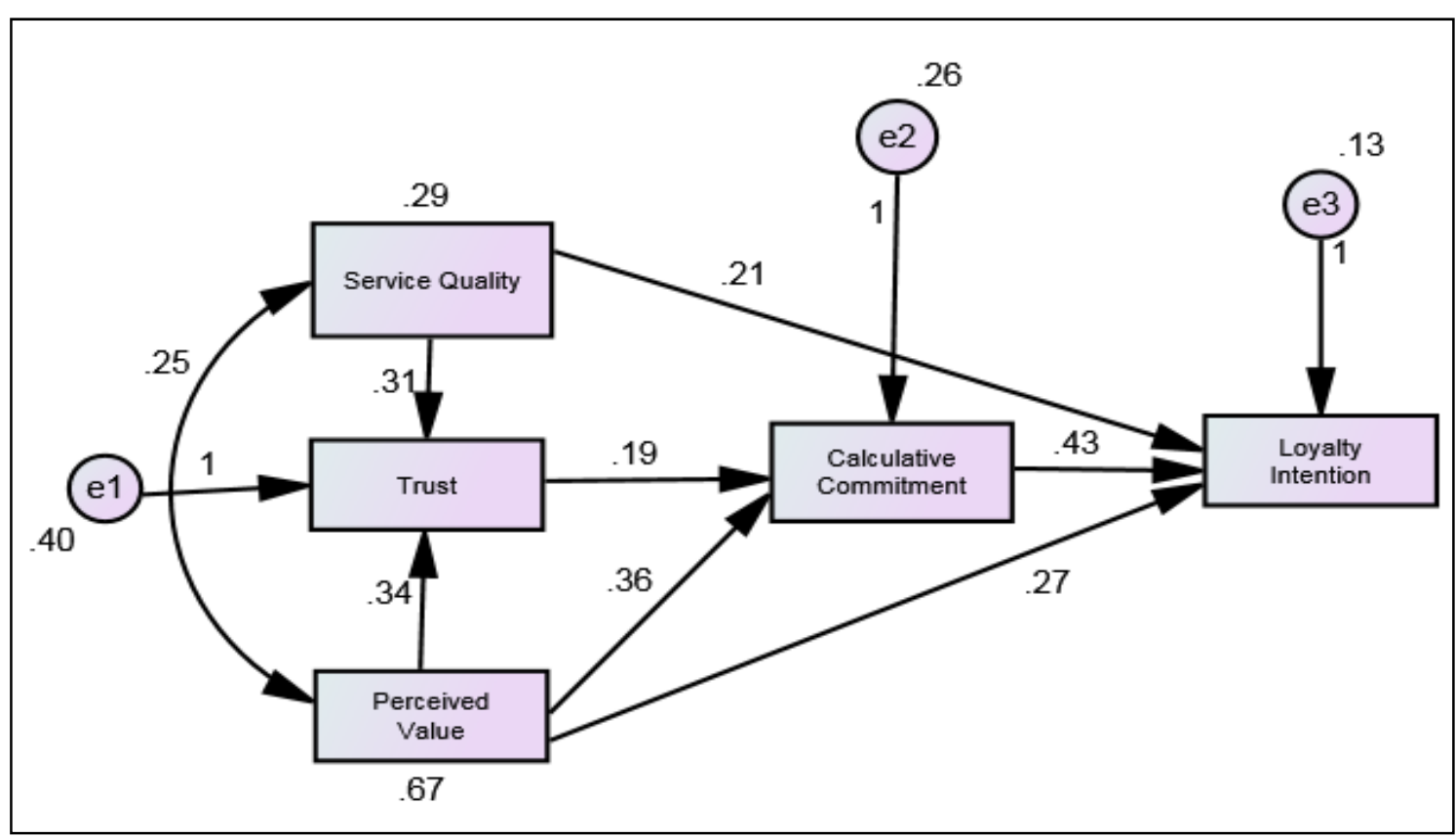

Figure 1. Research model. 
Table 8

FMIN

\begin{tabular}{lllll}
\hline Model & FMIN & F0 & LO 90 & HI 90 \\
\hline Default model & 0.021 & 0.005 & 0.000 & 0.074 \\
Saturated model & 0.000 & 0.000 & 0.000 & 0.000 \\
Independence model & 2.317 & 2.236 & 1.820 & 2.712 \\
\hline
\end{tabular}

Table 9

RMSEA

\begin{tabular}{lllll}
\hline Model & RMSEA & LO 90 & HI 90 & PCLOSE \\
\hline Default model & 0.049 & 0.000 & 0.192 & 0.377 \\
Independence model & 0.473 & 0.427 & 0.521 & 0.000 \\
\hline
\end{tabular}

Table 10

AIC

\begin{tabular}{lllll}
\hline Model & AIC & BCC & BIC & CAIC \\
\hline Default model & 28.596 & 29.918 & 65.364 & 78.364 \\
Saturated model & 30.000 & 31.525 & 72.425 & 87.425 \\
Independence model & 297.272 & 297.780 & 311.413 & 316.413 \\
\hline
\end{tabular}

Table 11

ECVI

\begin{tabular}{lllll}
\hline Model & ECVI & LO 90 & HI 90 & MECVI \\
\hline Default model & 0.231 & 0.226 & 0.300 & 0.241 \\
Saturated model & 0.242 & 0.242 & 0.242 & 0.254 \\
Independence model & 2.397 & 1.981 & 2.873 & 2.401 \\
\hline
\end{tabular}

Table 12

HOELTER

\begin{tabular}{lll}
\hline Model & HOELTER & HOELTER \\
& 0.05 & 0.01 \\
\hline Default model & 287 & 440 \\
Independence model & 8 & 11 \\
\hline
\end{tabular}

Notes. Estimates (Group number 1—Default model); Scalar Estimates (Group number 1—Default model); Maximum Likelihood Estimates.

Table 13

Regression Weights: (Group Number 1-Default Model)

\begin{tabular}{|c|c|c|c|c|c|c|c|}
\hline & & & Estimate & S.E. & C.R. & $P$ & Label \\
\hline $\mathrm{T}$ & $<---$ & SQ & 0.311 & 0.129 & 2.414 & 0.016 & \\
\hline $\mathrm{T}$ & $<---$ & PV & 0.341 & 0.084 & 4.044 & $* * *$ & \\
\hline CC & $<---$ & $\mathrm{T}$ & 0.194 & 0.070 & 2.764 & 0.006 & \\
\hline CC & $<---$ & PV & 0.363 & 0.064 & 5.668 & $* * *$ & \\
\hline LI & $<---$ & CC & 0.428 & 0.062 & 6.858 & $* * *$ & \\
\hline LI & $<---$ & PV & 0.272 & 0.055 & 4.949 & $* * *$ & \\
\hline LI & $<---$ & SQ & 0.214 & 0.074 & 2.914 & 0.004 & \\
\hline
\end{tabular}

Note. ***significant at $1 \%$. 
Table 14

Squared Multiple Correlations (Group Number 1-Default Model)

\begin{tabular}{ll}
\hline & Estimate \\
\hline T & 0.283 \\
CC & 0.373 \\
LI & 0.665 \\
\hline
\end{tabular}

\section{Discussions and Findings}

From the above tables, it is observed that the fit indices fitted perfectly the model with approximately all the fit indices being above 0.90 . Construct validity has been achieved through GFI, CFI being greater than 0.90 , and the RMSEA is less than 0.08 . The results (see Table 7) regression weights confirm that all the hypotheses (H1, H2, H3, H4, H5, H6, H7) have positive relationship.

The regression value of the paths between service quality and trust (0.311) supports H1, service quality and loyalty intention (0.214) supporting H2, trust and calculative commitment (0.194) supporting H3, perceived value and trust $\left(0.341^{* * *}\right)$ supporting $\mathrm{H} 4$, perceived value and calculative commitment $\left(0.363^{* * *}\right)$ supporting $\mathrm{H} 5$, perceived value and loyalty intention $\left(0.272^{* * *}\right)$ supporting H6, calculative commitment and loyalty intention $\left(0.428^{* * *}\right)$ supporting $\mathrm{H} 7$.

Most of the paths have positive relationship and also a significant impact on calculative commitment and loyalty intention like perceived value and trust $\left(0.341^{* * *}\right)$, perceived value and calculative commitment $\left(0.363^{* * *}\right)$, perceived value and loyalty intention $\left(0.272^{* * *}\right)$, calculative commitment and loyalty intention $\left(0.428^{* * *}\right)$.

\section{Limitations and Future Research Directions}

The present study relies on cross-sectional data to study customer loyalty. Longitudinal research is required to examine customer's long-term loyalty towards a company. This research does not examine the interaction effects between customer satisfaction and affective commitment. The study does not consider other factors influencing loyalty, such as network quality, consumer characteristics, length of relationship, type of connection used by customer (pre-paid vs. post-paid), and usage patterns.

Further research may incorporate the effect of variables like customer satisfaction, corporate image customer loyalty and examine more influences, interaction effects, and study its impact on development of behavioral and attitudinal loyalty. This study develops and validates the measures of customer loyalty and its antecedents for cell phone users. Future studies could consider to what extent the measures proposed in this study are valid in different service industries and what modifications need to be made in the scale items across different samples and contexts.

\section{References}

Abdolvand, M. A., \& Andervazh, L. (2011). Investigating customer perceived value in custom services. Asian Journal of Business Management Studies, 2(4), 162-165.

Anderson, J. C., \& Gerbing, D. W. (1988). Structural equation modeling in practice: A review and recommended two-step approach. Psychological Bulletin, 103(3), 411-423.

Andreassen, T.W., \& Lindestad, B. (1998). Customer loyalty and complex services the impact of corporate image on quality, customer satisfaction and loyalty for customers with varying degrees of service expertise. International Journal of Service Industry Management, 9(1), 7-23. 
Ashaduzzaman, M., Ahmed, S. M. S., \& Khan, M. M. (2011). Consumer choice behavior towards mobile phone operators in Bangladesh. International Refereed Research Journal, II(4).

Aydin, S., \& Ozer, G. (2005). The analysis of antecedents of customer loyalty in the Turkish mobile telecommunication. European Journal of Marketing, 39(7/8), 910-925.

Babakus, E., \& Boller, G. W. (1992). An empirical assessment of the SERVQUAL scale. Journal of Business Research, 24(3), 253-268.

Balaji, M. (2009). Customer satisfaction with Indian mobile services. The IUP Journal of Management Research, 8(10), 52-62.

Bansal, H. S., Irving, P. G., \& Taylor, S. F. (2004). A three-component model of customer commitment to service providers. Journal of the Academy of Marketing Science, 32(3), 234-250.

Bolton, R. N., \& Drew, J. H. (1991). A longitudinal analysis of the impact of service changes on customer attitudes. Journal of Marketing, 55(1), 1-10.

Brady, M. K., \& Cronin, J. (2001). Some new thoughts on conceptualizing perceived service quality: A hierarchical approach. Journal of Marketing, 65(July), 34-49.

Calvo-Porral, C., Faíña-Medín, A., \& Nieto-Mengott, M. (2017). Satisfaction and switching intention in mobile services: Comparing lock-in and free contracts in the Spanish market. Telematics and Informatics, 34, 717-729.

Cater, B., \& Zabkar, V. (2009). Antecedents and consequences of commitment in marketing research services: The client's perspective. Industrial Marketing Management, 38(7), 785-797.

Caruana, A. (2004). The impact of switching costs on customer loyalty: A study among corporate customers of mobile telephony. Journal of Targeting, Measurement and Analysis for Marketing, 12(3), 256-268.

Caruana, A., \& Ewing, M. T. (2010). How corporate reputation, quality, and value influence online loyalty. Journal of Business Research, 63(9-10), 1103-1110.

Chadha, S. K., \& Kapoor, D. (2009). Effect of switching cost, service quality and customer satisfaction on customer loyalty of cellular service providers in Indian market. The IUP Journal of Marketing Management, VIII(1), 24-37.

Chakraborty, S., \& Sengupta, K. (2013). An exploratory study on determinants of customer satisfaction of leading mobile network providers - Case of Kolkata, India. Journal of Advances in Management Research, 10(2), 279-298.

Chang, C. C. (2015). Exploring mobile application customer loyalty: The moderating effect of use contexts. Telecommunications Policy, 39(8), 678-690.

Chen, C. (2007). Perceived quality, perceived value, satisfaction and behavioral intentions for heritage tourists (pp. 1130-1136). Proceedings of the 13th Asia Pacific Management Conference, Melbourne, Australia.

Chen, J. S., \& Ching, K. H. R. (2007). The effects of mobile customer relationship management on customer loyalty: Brand image does matter. Proceedings of the 40th Hawaii International Conference on System Sciences.

Chen, L. K., \& Yang, W. N. (2015). Perceived service quality discrepancies between telecommunication service provider and customer. Computer Standards \& Interfaces, 41, 85-97.

Chiou, S. (2004). The antecedents of consumers' loyalty toward internet service providers. Information \& Management, 41(6), 685-695.

Chiou, J. S., \& Droge, C. (2006). Service quality, trust, specific asset investment, and expertise: Direct and indirect effects in a satisfaction-loyalty framework. Journal of the Academy of Marketing Science, 34(4), 613-627.

Clemes, M. D., Shu, X., \& Gan, C. (2014). Mobile communications: A comprehensive hierarchical modelling approach. Asia Pacific Journal of Marketing and Logistics, 26(1), 114-146.

Cronin, J., \& Taylor, S. (1992). Measuring service quality: A reexamination and extension. Journal of Marketing, 56(3), 55-68.

Dabholkar, P. A., Thorpe, D. I., \& Rentz, J. O. (1996). A measure of service quality for retail stores: Scale development and validation. Journal of the Academy of Marketing Science, 24(1), 3-16.

Davis, F. D. (1989). Perceived usefulness, perceived ease of use, and user acceptance of information technology. MIS Quarterly, 13(3), 319-340.

Davis, F. D., Bagozzi, R. P., \& Warshaw, P. R. (1992). Extrinsic and intrinsic motivation to use computers in the workplace. Journal of Applied Social Psychology, 22(14), 1111-1132.

Deng, Z., Lu, Y., Wei, K., \& Zhang, J. (2010). Understanding customer satisfaction and loyalty: An empirical study of mobile instant messages in China. International Journal of Information Management, 30(4), 289-300.

Desarbo, W. S., Jedidi, K., \& Sinha, I. (2001). Customer value analysis in a heterogeneous market. Strategic Management Journal, 22(9), 845-857. 
Dorsch, M. J., Grove, S. J., Darden, W. R. (2000). Consumer intentions to use a service category. Journal of Services Marketing, 14(2), 92-117.

Dubey, A., \& Dr. Srivastava, A. K. (2016). Impact of service quality on customer loyalty-A study on telecom sector in India. IOSR Journal of Business and Management (IOSR-JBM), 18(2), 45-55.

Eshghi, A., Haughton, D., \& Topi, H. (2007). Determinants of customer loyalty in the wireless telecommunications industry. Telecommunications Policy, 31(2), 93-106.

Gallarza, M. G., \& Saura, I. G. (2006). Value dimensions, perceived value, satisfaction and loyalty: An investigation of university students travel behavior. Tourism Management, 27(3), 437-452.

Garbarino, E., \& Johnson, M. S. (1999). The different roles of satisfaction, trust and commitment in customer relationships. Journal of Marketing, 63(2), 70-87.

Gijón, C., Garín-Muñoz, T., \& Pérez-Amaral, T. \& López-Zorzano, R. (2013). Satisfaction of individual mobile phone users in Spain. Telecommunications Policy, 37(10), 940-954.

Giovanisa, A. N., Zondirosb, D., \& Tomaras, P. (2014). The antecedents of customer loyalty for broadband services: The role of service quality, emotional satisfaction and corporate image. Procedia-Social and Behavioral Sciences, 148, 236-244.

Grönroos, C. (1984). A service quality model and its marketing implications. European Journal of Marketing, 18(4), 36-44.

Hong, P., \& Cho, H. (2011). The impact of consumer trust on attitudinal loyalty and purchase intentions in B2C e-marketplaces: Intermediary trust vs. seller trust. International Journal of Information Management, 31(5), 469-479.

Hsiao, C. H., Chang, J. J., \& Tang, K. Y. (2016). Exploring the influential factors in continuance usage of mobile social apps: Satisfaction, habit, and customer value perspectives. Telematics and Informatics, 33(2), 342-355.

Hur, W. M., Park, J. K., \& Kim, M. S. (2010). The role of commitment on the customer benefits-loyalty relationship in mobile service industry. The Service Industries Journal, 30(14), 2293-2309.

Kaur, H., \& Soch, H. (2013). Mediating roles of commitment and corporate image in the formation of customer loyalty. Journal of Indian Business Research, 5(1), 33-51.

Khayyat, N. T., \& Heshmati, A. (2012). Determinants of mobile phone customer satisfaction in the Kurdistan region. Journal of Knowledge Management, Economics and Information Technology, (3), 91-121.

Kim, C., Galliers, R. D., Shin, N., Ryoo, J. H., \& Kim, J. (2012). Factors influencing internet shopping value and customer repurchase intention. Electronic Commerce Research and Applications, 11(4), 374-387.

Kim, D. J., \& Hwang, Y. (2012). A study of mobile internet user's service quality perceptions from a user's utilitarian and hedonic value tendency perspectives. Inf. Syst. Front., 14(2), 409-421.

Kim, H. W., Chan, H. C., \& Gupta, S. (2007). Value-based adoption of mobile internet: An empirical investigation. Decision Support Systems, 43(1), 111-126.

Kim, H. W., Gupta, S., \& Koh, J. (2011). Investigating the intention to purchase digital items in social networking communities: A customer value perspective. Information and Management, 48(6), 228-234.

Kim, H., \& Yoon, C. H. (2004). Determinants of subscriber churn and customer loyalty in the Korean mobile telephony market. Telecommunications Policy, 28(9-10), 751-765.

Kuo, Y. F., Wu, C. M., \& Deng, W. J. (2009). The relationships among service quality, perceived value, customer satisfaction, and post-purchase intention in mobile value-added services. Computers in Human Behavior, 25(4), 887-896.

Lai, F., Griffin, M., \& Babin, B. J. (2009). How quality, value, image, and satisfaction create loyalty at a Chinese telecom. Journal of Business Research, 62(10), 980-986.

Lau, G. T., \& Lee, S. H. (1999). Consumers' trust in a brand and the link to brand loyalty. Journal of Market Focused Management, 4, 341-370.

Lee, D., Moon, J., Kim, Y. J., \& Mun, Y. Y. (2015). Antecedents and consequences of mobile phone usability: Linking simplicity and interactivity to satisfaction, trust, and brand loyalty. Information \& Management, 52, 295-304.

Leelakulthanit, O., \& Hongcharu, B. (2011). Factors that impact customer satisfaction: Evidence from the Thailand mobile cellular network industry. International Journal of Management and Marketing Research, 4(2), 67-76.

Lien, C., Wen, M., \& Wu, C. (2011). Investigating the relationships among E-service quality, perceived value, satisfaction, and behavioral intentions in Taiwanese online shopping. Asia Pacific Management Review, 16(3), 211-223.

Lin, K. Y., \& Lu, H. P. (2011). Why people use social networking sites: An empirical study integrating network externalities and motivation theory. Computers in Human Behavior, 27(3), 1152-1161.

Liu, D., \& Zhang, J. (2011). TAM-based study on factors influencing the adoption of mobile payment. China Communications, 8(3), 198-204. 
López-Nicolás, C., Molina-Castillo, F. J., \& Bouwman, H. (2008). An assessment of advanced mobile services acceptance: Contributions from TAM and diffusion theory models. Information and Management, 45(6), 359-364.

Lu, H. P., Lin, J. C. C., Hsiao, K. L., \& Cheng, L. T. (2010). Information sharing behavior on blogs in Taiwan: Effects of interactivities and gender differences. Journal of Information Science, 36(3), 401-416.

Lu, J., Yao, J. E., \& Yu, C. S. (2005). Personal innovativeness, social influences and adoption of wireless internet services via mobile technology. The Journal of Strategic Information Systems, 14(3), 245-268.

Martensen, A., Grønholdt, L., \& Kristensen, K. (2000). The drivers of customer satisfaction and loyalty: Cross-industry findings from Denmark. Total Quality Management, 11, S544-S553.

Morgan, M., \& Hunt, D. (1994). The commitment-trust theory of relationship marketing. Journal of Marketing, 58(3), 20-38.

Nikou, S., \& Bouwman, H. (2014). Ubiquitous use of mobile social network services. Telematics and Informatics, 31(3), $422-433$.

Niyi Israel, A., Temitope Emmanuel, A., \& Adenike Rita, A. (2016). Customers’ preference of mobile phone service providers in Ekiti State, Nigeria. British Journal of Marketing Studies, 4(2), 66-76.

Ou, W., Shih, C., Chen, C., \& Wang, K. (2011). Relationships among customer loyalty programs, service quality, relationship quality and loyalty: An empirical study. Chinese Management Studies, 5(2), 194-206.

Özer, A., Arganb, M. T., \& Argan, M. (2013). The effect of mobile service quality dimensions on customer satisfaction. Procedia-Social and Behavioral Sciences, 99, 428-438.

Pirc, M. (2006). Mobile service and phone as consumption system-The impact on customer switching. Proceedings of Helsinki mobility roundtable, Sprouts: working papers on information systems, 6(33).

Qian, S., Peiji, S., \& Quanfu, Y. (2011). An integrated analysis framework for customer value, customer satisfactory, switching barriers, repurchase intention and attitudinal loyalty: Evidences from China mobile data services. Management Science and Engineering, 5(3), 135-142.

Ranaweera, C., \& Prabhu, J. (2013). The influence of satisfaction, trust and switching barriers on customer retention in a continuous purchasing setting. International Journal of Service Industry Management, 14(1), 374-395.

Reichheld, F. F., \& Sasser, W. E. (1990). Zero defections: Quality comes to services. Harvard Business Review, 14(March), 495-507

Richard, J. E., \& Zhang, A. (2012). Corporate image, loyalty, and commitment in the consumer travel industry. Journal of Marketing Management, 28(5-6), 568-593.

Ryu, M. H., Kim, J., \& Kim, S. (2014). Factors affecting application developers' loyalty to mobile platforms. Computers in Human Behavior, 40, 78-85.

Shin, D. H. (2012). What makes consumers use VoIP over mobile phones? Free riding or consumerization of new service. Telecommunications Policy, 36(4), 311-323.

Shin, D. H. (2015). Effect of the customer experience on satisfaction with smartphones: Assessing smart satisfaction index with partial least squares. Telecommunications Policy, 39(8), 627-641.

Shin, D. H., \& Kim, Y. (2008). Forecasting customer switching intention in mobile service: An exploratory study of predictive factors in mobile number portability. Technological Forecasting and Social Change, 75(6), 854-874.

Suárezetal, D. (2016). Satisfaction of business customers with mobile phone and internet services in Spain. Telecommunications Policy, 40, 52-61.

Tarus, D. K., \& Rabach, N. (2013). Determinants of customer loyalty in Kenya: Does corporate image play a moderating role? The TQM Journal, 25(5), 473-491.

Taylor, S. A., \& Baker, T. L. (1994). An assessment of the relationship between service quality and customer satisfaction in the formation of consumers’ purchase intentions. Journal of Retailing, 70(2), 163-178.

Telecommunications in India (n.d.). In Wikipedia. Retrieved from https:en.wikipedia.org/wiki/Telecommunications in India

Wang, G. (2002). Attitudinal correlates of brand commitment. Journal of Relationship Marketing, 1(2), 57-75.

Wang, Y., Lo, H. P., \& Yang, Y. (2004). An integrated framework for service quality, customer value, satisfaction: Evidence from China's telecommunication industry. Information Systems Frontiers, 6(4), 325-340

Yang, Z., \& Peterson, R. T. (2004). Customer perceived value, satisfaction, and loyalty: the role of switching costs. Psychology \& Marketing, 21(10), 799-822.

Zeithaml, V. A. (1988). Consumer perceptions of price, quality, and value: a means-end model and synthesis of evidence. Journal of Marketing, 52(3), 2-22.

Zeithmal, V.A., Berry, L., \& Parasuraman, A. (1996). The behavioral consequences of service quality. Journal of Marketing, 60, 31-46. 
Zeithaml, V. A., Parasuraman, A., \& Berry, L. L. (1990). Delivering service quality. New York: Free Press.

Zhao, L., Lu, Y. B., Zhang, L., \& Chau, P. Y. K. (2012). Assessing the effects of service quality and justice on customer satisfaction and the continuance intention of mobile value-added services: An empirical test of a multidimensional model. Decision Support Systems, 52(3), 645-656. 